\title{
Social Psychology: Fundamentals and Fundamentalisms
}

\author{
Marcus Eugênio Oliveira Lima ${ }^{1}$ \\ Departamento e Mestrado de Psicologia da Universidade Federal de Sergipe, \\ Aracaju, Sergipe, Brasil
}

\begin{abstract}
This manuscript proposes a theoretical analysis of the lack of contact between the different social psychologies existing in Brazil. We present two viewpoints that characterize extreme positions in the discipline, on the one hand a more empirical social psychology; on the other a social psychology predominantly theoretical and anti-empirical. Lack of contact feeds stereotypes and prejudices, which, in turn, create a vicious cycle that creates and expands differentiation between groups, feeding ethnocentric blindness. In conclusion we propose that the lack of contact between the more empiricist social psychology and the critical social psychology renders the first irrelevant and the second dogmatic, with wide repercussions for the area's bibliographic production, the formal training of social psychologists, and professional meetings.
\end{abstract}

Keywords: Social Psychology, tensioning, integration and development.

\section{Psicologia Social: Fundamentos e Fundamentalismos}

\section{Resumo}

Este manuscrito se constitui numa proposta de análise teórica de algumas das consequências da falta de contato entre as diferentes psicologias sociais existentes no Brasil. Propomos dois eixos que configuram posições extremadas na disciplina, de um lado uma psicologia social mais empírica; de outro, uma psicologia social predominantemente teórica e anti-empírica. A falta de contato alimenta estereótipos e preconceitos, os quais, por sua vez, criam o ciclo-vicioso que constrói e amplia as diferenciações entre os grupos, alimentando a cegueira etnocêntrica. Finalmente, propomos que a falta de contato entre a psicologia social mais empirista com a psicologia social crítica torna a primeira irrelevante e a segunda dogmática, com amplas repercussões na produção bibliográfica da área, na formação dos psicólogos sociais e nos congressos profissionais.

Palavras-chave: Psicologia Social, tensionamento, articulação e desenvolvimento.

Endereço para correspondência: Av. Orlando Tavares Macedo, 800, Aruana, Aracaju, SE, Brasil 49000-447. E-mail: marcuseolima@gmail.com

Agências de Financiamento: Coordenação de Aperfeiçoamento de Pessoal de Nivel Superior (CAPES).

The authors wish to acknowledge the valuable critical comments and suggestions from Pedro de Oliveira Filho (Universidade Federal de Campina Grande [UFCG]) and Cicero Roberto Pereira (Instituto de Ciências Sociais da Universidade de Lisboa [ICS-UL] - Portugal). We extend our thanks also to Professor José Ramón Torregrosa Peris (Universidad Complutense de Madrid [UCM] - Espanha) for instigating comments about social psychology. 


\section{Psicología Social: Fundamentos y Fundamentalismos}

\section{Resumen}

Este manuscrito propone un análisis teórico de la falta de contacto entre las diferentes psicologías sociales existentes en Brasil. Se presentan dos puntos de vista que caracterizan las posiciones extremas en la disciplina, por un lado, una psicología social más empírico, y por otro una psicología social predominantemente teórica y anti-empírico. La falta de contacto alimenta estereotipos y prejuicios, lo que, a su vez, crea un círculo vicioso que expande la diferenciación entre los grupos. En conclusión, proponemos que la falta de contacto entre el más empirista psicología social y la psicología social crítica hace la primera sufrir de falta de pertinencia y la segunda se convierte en dogmática, con amplias repercusiones en la producción de lo conocimiento, la capacitación formal de los psicólogos sociales y conferencias profesionales.

Palabras clave: Psicología Social, tensión, integración y desarrollo.

Plato, in a famous parable, tells us about men living in a cave, separated from the outside world by a wall, having access to information from the outside only by an opening through which passed a beam of light, and restricted to seeing only the back of the cave, where the shadows from the outside are projected and where they hear sounds from those on the outside; the shadows are reality for those men. Such much so that if one of them was to go out one day and returned to recount this to the rest, he would be ignored or viewed as crazy, and could even be killed by the others ${ }^{2}$. Something in this Platonic allegory can help us understand what is happening in current-day Brazilian Social Psychology.

In this article, we attempt to examine some of the consequences of the lack of contact between social psychologies existing in Brazil. We intend to show that there are possible points of connection between them, and that the clash between their differences is necessary for the development of psychosocial knowledge. Initially, we will discuss the meta-theoretical viewpoints that form a predominantly empirical social psychology as opposed to a social psychology predominantly theoretical. The hypothesis of our analysis is that the lack of contact between these two liturgies undermines the possibilities of deeper psychosocial analysis on pressing issues of the social world.

\footnotetext{
Plato (trans. 1993).
}

We start from the assumption that undertaking an analysis of Brazilian social psychology requires an understanding of its principal canons in the American and European social psychologies. In this sense, although the subject of our analysis is the social psychology produced in Brazil, we are interested in analyzing the results of the isolation of their main theoretical and methodological currents or perspectives, rather than undertake a detailed in-depth study about the various types of national psychosocial production.

We will analyze, on one hand, fundamentals and possibilities of what is conventionally called "critical social psychology", also very closely related in Brazil to the "Socio-historical Approach" (Souza \& Souza, 2009), although there are considerable theoretical and methodological differences between them ${ }^{3}$. On the other hand, we will focus on a more empiricist social psychology, inspired by Anglo-Saxon models. Evidently, this classification simplifies and even reduces the complex and multiple meta-theoretical positions that constitute the field of social psychology into only two axes,

3 Particularly in the case of the socio-historical followers of Vygotsky's approach. For many of them, constructionism leans close to the bourgeois ideals they criticize. In this regard, see the book by Newton Duarte (2001), Vygotsky and learning to learn: Critique of neoliberal and postmodern appropriations of Vygotskyan theory ( $2^{\text {nd }}$ ed.). Campinas, SP: Campinas Autores Associados. 
empiricist and constructionist. Nevertheless, we take the didactic liberty to cite one type of social psychology more centered on hypothesis testing, and another more focused on understanding the processes of meaning and language.

Even so, we know that there are no pure positions, and that they form a continuum much more than a dichotomy. This does not preclude, however, each of these axes from considering itself as a bearer of truths from the outside world, and pari-passu, considering the other as being contaminated by shadows and by error (Gergen, 2002).

We will argue further on about the processes of differentiation in social psychology in Brazil, with the aim of demonstrating that the antagonistic positions already in place have hindered the development of the area, and that many of the constructed distinctions are sustained by prejudiced simplification processes, since both empiricism and constructionism have similar epistemological origins (Jost \& Kruglanski, 2002). Then, finally, considering that social psychology would gain much by the theoretical and methodological pluralism that the encounter between these meta-theories would produce, we present a proposal for a dialogic tensioning between these positions toward configuring an effective psychosocial space.

\section{Differences and Differentiations: Common Origins and Divergent Practices}

Clifford Geertz opens his chapter on Jerome Bruner's contributions to psychology thus:

From the outside at least, psychology does not seem like a single field, divided into schools and specialties in the usual way. It looks like an assortment of disparate and unconnected inquiries, classed together because they all make reference in some way or other to something or other called "mental functioning". Dozens of characters in search of a play. (Geertz, 2001, p. 166) ${ }^{4}$
This seems like a good portrait of the situation of psychology in general, and of social psychology in particular. To be sure, we cannot even speak of social psychology in the singular, as we run the risk of being misunderstood. Better "social psychologies", some more in the style of the American school, what is conventionally called "psychological social psychology"; others in the European fashion, the "sociological social psychology" (Farr, 1999). Or even, complicating things further, one from the German school, "the critical social psychology", another from the British school with a run through France, "discursive social psychology" style, and yet another from the Russian school, "the socio-historical psychology" (Alvaro \& Garrido, 2006; Rey, 2004; Sá, 2013).

In this scenario, it is common that the social psychology congresses define themselves as theoretical-methodological churches where the faithful of a given perspective flock, and from which those of other faiths "run like the devil from the cross". They never meet, except sometimes in airport lobbies or in departments in their universities, but try to speak in amenities so as to maintain good relations. As Doise (2002, p. 27) relates:

Even when, in the same meeting, these different flocks are represented, the usual practice of symposia and workshops running in parallel allows the representatives of the different persuasions to not meet, remaining among their coreligionists, and if I may say so, thus avoiding religious wars. Such situations allow the attack on divergent positions, without any appearance by the opposition ${ }^{5}$.

In Brazil, the radicalization among the meta-theoretical schools and positions marked the establishment of the psychosocial field from the start (Camino \& Torres, 2011). In our country, the positions are so radicalized that they produced, on one hand, a social psychology that is ashamed of psychology, anti-psychological in its essence, and often anti-empiricist in its practice; 
and on the other, a social psychology that ignores the contributions of social science, anti-sociological, micro-theoretical, and often atheoretical. Two leading figures in the creation of Brazilian Social Psychology, Aroldo Rodrigues and Silvia Lane, are emblematic of this phenomenon and are notable even today as the main authorities in the field (Lima \& Techio, 2013).

As already mentioned, there are, in this paroxysm, many intermediate positions; pure cases being rare. Nevertheless, the radicalization of positions created the psychological and political conditions for affiliation and non-affiliation with the theoretical-methodological possibilities that were presented in the arena of social psychology's emergence in Brazil. A typical case of intergroup conflict that social psychology itself can help us understand.

As Henri Tajfel (1983) relates, analyzing the relationship between intergroup conflict and construction of social images and identities, one of the main socio-cognitive consequences of the categorization of the social world into "us" and "them" is the simplistic perception that "they", the others from the other group, are all equal to each other, and at the same time, worse than "us", who are better and unique. This process constitutes the cognitive soil to the emergence of ethnocentrism, stereotyping and prejudice against difference. Lévi-Strauss (1952/2000) asserts that when we are put in unexpected situations, our more usual attitude is one that purely and simply repudiates the cultural, moral, religious, social, and aesthetic forms furthest from those with which we identify.

In fact, our short history shows that each of the Brazilian social psychologies tends to repudiate the other as "barbaric", because it does not share the same theoretical and methodological assumptions. However, as Lévi-Strauss (1952/2000, p. 19) himself relates: "The barbarian is, first of all, the one who believes in barbarism". We do not deny that there are important differences between the social psychologies. However, we argue that there are also many differentiations, that is, processes that fabricate and overvalue the differences.
According to Jost and Kruglanski (2002), the main difference between constructionistinspired social psychology and more empiricist social psychology lies in the notion of "representation of reality". For the constructionists, such representations are arbitrary and relative. They feel that reality and knowledge about it are discursive practices. Such that the problems the "scientists" encounter can often be better investigated by artists and even journalists, than by theorists. As Woodiwiss (1990, p. 3) relates, describing post-structuralism: "By contrast, according to the theory of meaning first posited by Saussure, words (including the theories) do not represent extralinguistic realities". The criticism, therefore, is not aimed at the term "representation" in itself, but at the possibility that scientific knowledge may be a representation of reality. The empiricists, however, believe that it is possible to produce knowledge or representation of a reality that is not limited to discourse, that is extra-discursive. They are in search of data that represent reality, in the most verisimilar and accurate manner, quite often adopting probabilistic models toward this end.

Although representationism may be a marked difference between these paradigms, there is also a fundamental similarity between them, their origin. According to Jost and Kruglanski (2002), the central assumptions of the two perspectives arise from the same ground, and stem from philosophers such as Marx, Hegel, Weber, Durkheim, Simmel, Cooley, Dewey and Mead, who inspired both the more empirical analyses as well as those more speculative and subjective: "In this sense, the intellectual origin of empiricist psychology and of constructionist psychology is essentially the same" (Jost \& Kruglanski, 2002, p. 170). It is important to note that there are other fundamental philosophical references, such as Nietzsche, Heidegger, and Wittgenstein, that mark important distinctions.

Jerome Bruner and Vygotsky are notable references for this possibility of common origin and contact between the empiricist and constructionist paradigms in social psychology. Bruner worked in almost all lines of thought. He was 
one of those responsible for the cognitive revolution, creating along with Goodman in the 1940s, the "new look in perception", a movement that inaugurates social cognition, the main axis of the more empiricist social psychology even today. Before that, he had worked with rats in maze learning activities. Later he became disenchanted with cognitivism, upon thinking that it had become too technical, and became interested in cultural psychology, trying to understand how individuals engage in processes of sharing meanings, beliefs, and values already established in society, focusing on the social production of meaning, and proposing the analysis of narratives as a method (Bruner, 1990; see also Geertz, 2001). Vygotsky (1996), integrating influences of Darwin, Marx, Durkheim, and Köhler, through ingenious experiments, analyzes the importance of the other in the development of inner speech or thought in children, and creates a field of fundamental influence for constructionism, the socio-historical approach.

But, although there is no marked difference in the origin of the paradigms, there is great difference in their practices, as is stated by Kenneth Gergen, a leading figure of constructionism. According to this author, the most important difference between constructionist and empiricist social psychologists is found on a meta-theoretical level. Constructionism would be rooted in the sociology of knowledge and in the history of science, while empirism would be based on experimentalism (Gergen, 2002). However, despite this difference between the two paradigms, Gergen himself states that closer relations between them would be beneficial for both, and for social psychology as a whole:

Empiricist philosophers have rightfully avoided any proposals for submitting empiricist foundations to empirical test. How could empirical methods be used to falsify the grounds on which they rest? In addition, most constructionists would agree that constructionist views of knowledge are themselves the outcome of social negotiation. In fact, philosophers in general have largely abandoned the attempt to secure a universal "foundation" of knowledge .... We might fruitfully discontinue the mad rush to a higher ground and begin to ask about the relative merits of differing perspectives. (Gergen, 2002, p. 189)

Indeed, the merits of each of these views of the world and of knowledge would gain in strength if they were to engage in more contact. We will address this point in the next section.

\section{The Etiology of Prejudice: Ignorance and Lack of Contact}

In the relations between social groups, social psychology has shown, since the 1950s, that the lack of contact feeds stereotypes and prejudices, which, in turn, create a vicious cycle that amplifies the differences between the groups and feeds conflict (Lima, 2011). However, social psychology itself is a victim of the phenomenon that it describes so well.

The lack of contact between the dominant paradigms weakens the two perspectives and can be one of the causes of the fact that social psychology has never produced a theory with social impact, as did, for example, Freud and Skinner. For Gergen (1978), social psychology has not been very successful in producing an intellectual revolution that affects our conceptions of nature or the human condition.

In the more empiricist psychology, the lack of contact with critical approaches has generated micro-theorizing and little theoretical creativity or inventiveness. According to Kruglanski (2001), the main negative consequences of the theoretical shyness of empiricist social psychology can be seen in practices such as: (a) inventing new names for old concepts, (b) fragmentation of the field, (c) loss of value and interest, and (d) isolation in the dialogue with other knowledge areas.

Inventing new names for old phenomena amounts to re-christening concepts in order to pose as discoverers and creators of a theory. For example, in the field of theories about prejudice, Social Dominance Theory - SDT (Sidanius, 1993) was recently created, and with it, the interest in a phenomenon or psychological trait, social dominance orientation (Pratto, Sida- 
nius, Stallworth, \& Malle, 1994). However, in the 1950s, the sociologist Herbert Blumer had already formulated the Theory of the Sense of Group Position (Blumer, 1958), whose assumptions are identical to those of SDT. Another example is the Theory of Benevolent Sexism, by Glick and Fiske (2001), which already appears in the sociological description by Mary Jackman (1994) on paternalism. Each of us could make an effort and search within their fields, for social psychology theories that are original and have brought innovative contributions in recent times. Clearly, we have no wish to detract from the merit of these psychosocial theories on providing empirical support to the theories of Blumer and Jackman. However, this seems a trifle for a field as vast as social psychology.

The fragmentation of the field is related to Social Psychology's difficulties in connecting with other knowledge domains, thus becoming a discipline whose explanations for phenomena usually involve a broad and diverse set of factors that are often contradictory. For example, in the area of current psychosocial theories to explain interpersonal attraction, a researcher can formulate both the hypothesis that similarity generates attraction, as well as the opposite hypothesis, that difference is the cause of attraction. For both statements, there is broad confirmatory empirical evidence (McGuire, 1973).

Another limitation that the lack of contact or dialogue between the social psychologies carries is the decline in value and interest. To check the validity of this assertion, we need simply ask our students to read the articles published in journals of the area, especially the most influential, and then tell us to what extent, in general, they are interesting. Such an assessment was already taken on texts published in the Journal of Personality and Social Psychology, by Kay Deaux in 1988, and the most frequent response was: "journal articles are no longer interesting" (cited Kruglanski, 2001, p. 873).

Finally, the isolation of the broader cultural dialogue is another limitation of social psychology closed in upon itself (Kruglanski, 2001). The author proposes that this leads researchers to a reluctance toward theorizing and venturing beyond their data or assumptions, which makes the voice of this social psychology barely heard and of slight influence in the intellectual debate on social issues. Gergen (1978) also discusses "theoretical timidity" as one of the limitations of social psychology. To him, many of our theories fail for lack of generative power (i.e. do not demonstrate a capacity to challenge prevailing beliefs about social life, or are unable to offer alternatives to contemporary standards of conduct).

In this regard, one needs only to take a look at the articles published by the two leading journals of social psychology in Europe and the United States. They rarely have more than three pages of theory, most of the text being devoted to the method and the results, closing with a couple of pages of discussion and a much larger number of pages devoted to references. However, one could argue that these journals are devoted to research reports and that there are specific channels to trickle out the theoretical production of the area. That is indeed true, but even the journals that are dedicated to publication of theoretical papers have been going through a sort of crisis of content. As Kruglanski (2001, p. 874) tells us:

Susan Anderson, currently an associate editor at Psychological Review, admits to "having been surprised by the large numbers of papers even by top notch players in the field that are really literature reviews and don't present a well-developed, internally coherent theory that is in fact new" (personal communication, 1999). Marilynn Brewer, our outgoing editor of Personality and Social Psychology Review (PSPR) adds that "submissions to PSPR have not produced much by way of broad, general theory". (personal communication, 1999)

Even though Kruglanski's analysis focuses more on one type of social psychology, it is plausible to imagine that these problems also occur in the other social psychology, the critical. Nevertheless, there are yet other limitations, these specific to the more empiricist social psychology, that a greater openness to other theoretical and methodological possibilities could avoid. 
One of these relates to the ongoing and even exclusive use of college students in research studies. The vast majority of these individuals have a socio-demographic profile that varies little, they are generally middle-class, young, white, Catholic, etc. They are what Henrich, Heine and Norenzayan (2010) call "WEIRD" (Western, very Educated, Industrialized, Rich, and Democratic). College students constitute $96 \%$ of the subjects of the research published in the six leading journals in psychology, between 2003 and 2007 (Jones, 2010).

In fact, if we consider the main European social psychology journal (European Journal of Social Psychology), among 67 articles published in 2011 (from the edition numbers 1-6), 62.5\% had samples exclusively from college students and almost always from psychology courses. Another $17.2 \%$ had mixed samples and only $20.3 \%$ of the articles did not use this type of sample in their studies. That is, only one in five of the articles published in the main European Social Psychology Journal present studies conducted with ordinary citizens. This leads us to question the extent to which the theories produced in modern social psychology can be applied to other groups and other contexts outside the university.

The excessive use of this type of sample in the studies can result in misleading formulations about phenomena with utmost importance, which carries significant social risks, as Gergen (2002, p. 189) well observed: "When we begin to declare local truths as true in all worlds, we not only border on insensitivity, but we may ultimately contribute to forces of colonialism, oppression, and totalitarianism". Less dramatically, Henrich et al. (2010) show that even the perception of physical stimuli varies culturally; to cite just one example, the Muller-Lyer illusion, which concerns the belief that line $\mathrm{A}$ is shorter than line $\mathrm{B}$, is more frequently perceived among subjects from industrialized societies than in less industrialized societies.

Again we can draw an example of these risks from our area of research. The Theory of Aversive Racism formulated by Gaertner and Dovidio (1986) states that when people are confronted with inter-racial contact situations in which the appropriate response is clear, in which right and wrong are clearly defined, aversive racists do not discriminate against Blacks (see Lima, 2011). Empirical evidence of this theory shows that in situations of job candidate selection, Blacks will only suffer discrimination in relation to Whites when both have median qualifications for the position; in situations of high and low qualification, as the responses to hire or not are clearly defined by the norm, racism will not be a factor (Dovidio \& Gaertner, 2000). However, Quillian (2006), using data from American employment agencies concerning hiring that occurred between 1994 and 2003, shows that real life is not like that. The accounts from business owners indicate that Whites are hired 2.43 times more than Blacks when the interview is face-toface, and 1.5 times more when the interview is by computer, even when all candidates have the same level of schooling.

Thus, we can conclude that the data from Dovidio and Gaertner (2000) derive from the irrelevance of the activity for American college students who, when responding to hiring simulations, attempt to show they are not prejudiced. Whereas the businessmen surveyed, when placed in a real situation, prefer to hire Whites over Blacks, and probably have justifications supposedly unbiased against Blacks, as demonstrated in other studies (e.g., Pereira, 2007; Pereira, Torres, \& Almeida, 2003; Pereira \& Vala, 2011).

Another marked limitation in the field of current empirical social psychology stems from an experimental research model that is formatted not to test hypotheses, but to confirm them. In Brazil, this aspect of the experimental methods in social psychology has always been approached from the perspective of an exorcist trying to cast out the devil (experiment) from the sinful positivist body (social psychology; e.g., Tittoni \& Jacques, 1998). However, the biggest problem of experimental research in social psychology is far from being the supposed belief in the neutrality of knowledge; it relies much more on the lack of openness to error, and perhaps even on the current lack of neutrality in the method.

William McGuire (1973), analyzing experimental research in social psychology over 
the course of time, states that formerly this method was creative and critical. We need only to recall the experiments of Muzafer Sherif on the relation between competition, stigma, and prejudice, those of Vygotsky on inner speech in children, those of Henri Tajfel on social identity; and even the quasi-experiments of Luria on the relation between the perceptions of geometric shapes and the cultural insertion of groups, and along the same line, those of Bruner and Goodman, or even the study by Bartlett on culture and memory, and by Asch on the size of the lines, just to name a few. However, for McGuire, more recent experimental research fails to account for the complexity of the psychosocial processes and even further, eventually constitutes an exercise of confirming theories, losing its essential function of hypothesis testing: "The crux of this objection is that we, social psychologists, have tended to use the manipulational laboratory experiment not to test our hypotheses but to demonstrate their obvious truth" (McGuire, 1973, p. 448).

Actually, all those who have done experimental studies know that if the "results are not found" (i.e., if the hypotheses or theoretical assumptions are not confirmed, the research is not suitable for publication in the area's major journals). Who of us has read, in the European Journal of Social Psychology or in the Journal of Personality and Social Psychology, reports of wretched researchers who went about not confirming their hypotheses. The stories are all successes, the empirical evidence always appears; either due to the use of a statistical apparatus so sophisticated that at some point the data will have to confess what is expected of them, or because the experiment will be repeated with other subjects (usually paid for their responses), using other procedures and instruments until the hypothesis is finally confirmed. In fact, among those aforementioned 67 articles published in the European Journal of Social Psychology in 2011, 58.2\% were experimental studies and they all confirmed their hypotheses.

It is not without cause, as we have seen, that we can have diametrically opposed hypotheses on the same phenomenon and both will be confirmed; because what is being tested, basically, are not hypotheses, but the ability of the researcher to confirm them: "If the experiment does not come out 'right', then the researcher does not say that the hypothesis is wrong but rather that something was wrong with the experiment" (McGuire, 1973, p. 449).

This phenomenon has most varied consequences, both epistemological and ethical. In 2011, European social psychology was confronted with a scandalous case of fraud. Dutch researcher Diederik Stapel confessed to have faked his laboratory data, inventing information that was published in dozens of major scientific journals. Altogether, 30 articles in respected scientific journals included data created by Stapel. One explanation for the non-discovery of the researcher's frauds was the lack of scientific criticism ${ }^{6}$. However, in order to understand what leads a researcher to falsify data, it may be important to carry out, as stated by Fabrizio Butera, president of the European Association of Social Psychology in a letter to the scientific community on September 9, 2011, a more systemic analysis, considering the culture that has been fostered on what is "good research" and what is "a good researcher" in the extremely competitive research scenario in which we live today. It is in this direction that Eric-Jan Wagenmakers states:

But when we do our statistics, we feel the same pressure to publish, we are subject to the same confirmation biases, and I doubt that we can lay claim to a higher morality. I suspect, therefore, that we torture the data just as much as social psychologists do. ${ }^{7}$

If we combine this eagerness to confirm hypotheses with the assertions about theoretical timidity, lack of generative theories, or the current sterility of the theoretical field in social psychology, then we have a disheartening scenario, in which processes occurring under certain research conditions, generally in middle-class

For more details see http://m.rnw.nl/portugues/ node $/ 85887$

7 For more details see http://www.ejwagenmakers. com/2012/Wagenmakers2012Horrors.pdf 
college students, turn into the self-confirmatory theories that structure knowledge in the area and generate "new" studies, which are conducted to confirm old assumptions.

All of this has an impact on the professional training of students and researchers in social psychology. They do not learn about how to formulate good hypotheses, and proceed to neglect the knowledge of classical texts by reading articles that never have more than four pages of theory, and therefore teach nothing about how to theorize. This generally involves students with lots of statistical or technical resourcefulness, but with low critical thinking on the theory being embraced, and little creativity for changing it. Students who attend the same scientific congress as their advisors, where they will discuss and hear basically what they have already heard and discussed at their universities.

But will the situation of the constructionist analyses, which have emerged as a scathing criticism of this empiricist psychology, be a better world?

Woodiwiss (1990), analyzing the impact of postmodernism on social theory, states that by having abandoned realism, postmodernists have restricted their analyses to criticism about particular concepts (e.g., class, society, identity), have affirmed the illusory nature of the theories about these phenomena, but have ignored the concept that knowledge itself, as a set of discursive practices, is a social fact, for it has a materiality and therefore can be observed and described. In the words of Woodiwiss (1990, p. 9):

By refusing what might be termed "the rush to representation" we could imagine that this would enhance the likelihood of a fruitful union between theory and observation, in which the role of observation was to control abstraction rather than to initiate, verify, or falsify it.

However, that was not quite what happened with constructionism, which generally was limited to criticism. Weinberg (2008) declares that the almost exclusive commitment to deconstruct intellectual projects may reflect a certain philosophical immaturity in the constructionist movement. According to this author, constructionist research can not avoid the performative assumption that to be about something, the imagination has to encounter reality; analyzing language does not exempt us from considering the objectivity of things. Such that, reading brilliant writers like Foucault, Derrida, Nietzsche, and Rorty leads the constructionist movement to devalue the scientific descriptions of social phenomena in favor of literary and philosophical narratives (Weinberg, 2008). But we must take into account, as Habermas teaches us, that replacing the reasonableness of an argument with its beauty is to produce sustenance for the demagogues. Thus: "Although our judgment criteria often intersect, it remains important to differentiate the beauty of the argument from its empirical substantiality" (Weinberg, 2008, p. 32).

In the same direction, Jost and Kruglanski (2002) argue that considering the "truth" as a product of scientific activity is different than considering the "truth" as an ideal or guide of epistemic activity. In such a manner that the constructionist theses on language games and their criticism of meta-narratives and universalist ontologies should be empirically analyzed in constructionist terms (Gergen, 2002; Weinberg, 2008).

There is also some contradiction in the anti-foundationalism of constructionism, as this is often advocated by the followers of this approach as the most correct epistemological position. However, as Castañon (2004) questions, on what basis can one assert the epistemological superiority of a given way of thinking, if there are no secure foundations to assess any knowledge? Furthermore, Méllo, Silva, Lima, and Di Paolo (2007), citing one of the Gurus of constructionism in Brazil, Lupicinio Íñiguez, question whether constructionism in social psychology still retains all its original rebelliousness or has already become a new form of orthodoxy, adopting the same practices of exclusion of the different that it suffered when it first appeared.

Ideologically, there are other contradictions in constructionism that generate ambivalences in their analyses which deserve mention. We have heard many times that poststructuralist approaches are aligned with libertarian ideals of 
social equality, of the fight against the establishment, which form a position to the left on the political spectrum (see Hepburn, 2003); or even that qualitative analyses, which characterize this meta-theory, are liberating, as opposed to quantitative analyses focused on control (for a critique see Bauer \& Gaskell, 2002).

However, in the philosophical heart of constructionism, in particular its founding idea that external reality is unknowable, is a legacy of the political right, deriving from the Idealism and skepticism of Berkeley, Descartes, Hume, Kant, and Hegel, as opposed to Marxist ideas (Jost \& Hardin, 1996; Weinberg, 2008). This ideological ambivalence generates internal contradictions that are reflected in practice: "The philosophical implication is that people are not really oppressed, but they think they are. This turns the perception of injustice into just one among many equally (in)valid social constructs" (Jost \& Kuglanski, 2002, p. 175).

Camargo (2012), citing an internal criticism of the constructionist paradigm, produced by Bruno Latour, states that often the relativism of the critical approach to science is co-opted by conservative, religious, and fundamentalist ideologies; in such a way that

the danger, in this case, comes not from ideological arguments presented as facts, but from excessive distrust of matters in fact reasonable, disguised as reprehensible ideological biases ... . In short, we may criticize Reason, without forgetting that its sleep, as Goya put it, produces monsters. (Camargo, 2012, p. 16)

In Brazil, constructionism was more inspired by the ideas of Foucault, Lacan, Derrida, Deleuze and Guatari, with emphasis on radical criticism of the hegemonic modes of addressing subjectivity and the processes of subjectification (Dimenstein, 2000; Leite \& Dimenstein, 2002) and their relationship with modernity (Mancebo, 2002). Constructionism in Brazil largely abandons the frameworks of discursive psychology (e.g., Billig, 2008; Potter \& Wetherell, 1987) and American constructionism (e.g., Gergen 1973, 1978, 1994), to adopt a perspective markedly anti-psychologizing. Indeed, just hearing the word "psychologizing" causes hives to many local constructionists. This brought to social psychology a kind of theorizing that ignores the classic texts of psychology in general, and social psychology in particular.

In fact, if we look at the book "Psicologia Social Contemporânea" [Contemporary Social Psychology], published in 1998, in several chapters there is hardly any classic work of psychology cited. In the chapter about identity, for example, from the classical and recent authors of social psychology on identity, only George Mead is cited, taking up two lines of text, followed immediately in the next sentence by the statement that the naturalist, essentialist, and maturationist perspectives of identity were questioned in contemporary approaches (Jacques, 1998). There is no mention of the theories of social identity of the Bristol and Geneva Schools or even of the constructionist theories of identity in social psychology, such as those of Gergen or from the Discourse Analysis group in England. As we read the chapter, we get the feeling that it is the first time a social psychologist writes about this topic.

We think the anti-empiricism and antipsychologism that characterize constructionist social psychology in Brazil held its political importance, for opposing an individualistic social psychology and for opening a new scenario where a more critical psychology flourished, with a broader vision of the social (Silva, 2004). However, theoretically and methodologically, it is a stance as empty or shallow as the antisociologism of the other radicalized perspective. For Moscovici (1990), a "psychologizing analysis", in academic parlance, means a reductionist analysis; while a "sociologizing analysis" is a compliment, a reference to a broad and complex approach. Nevertheless, there is no more analytical power in one than in the other, both are reductionist. Moscovici (1990, p. 19) quotes Thomas Mann to brilliantly illustrate this movement of repudiating the psychological:

Psychology, mercy, you're still at it? This is but a nineteenth-century bourgeois affliction! Our age is woefully saturated with it, soon we will have a violent fit of choler at 
the mere word "psychology", and whoever disturbs life by involving oneself in psychology will simply receive a blow to the skull.

From our point of view, the anti-psychologism of constructionism in Brazil impoverished the internal debate on social psychology and eventually helped turn our main scientific congresses into a theoretical-methodological corporation with a single voice. Illustrative of this phenomenon, the Revista Psicologia \& Sociedade [Psychology \& Society Journal], the leading journal in the area, had proposed in 2012 a special issue in English, for which critical social psychology was defined as an approach to be adopted by the authors: "A call was made for contributions that carried out, from the theoretical framework of critical social psychology, analyses and reflections on the problems and context of the Brazilian and Latin American societies" (Mayorga, Rasera, \& Prado, 2012, p. 492).

Once again, the exaggeration of positions has an impact on the education of our students and future researchers. On this side of the Equator they usually become "amateur sociologists or philosophers" with little reading of classic texts of general and social psychology, and with colossal prejudices against all research that is not qualitative, and sometimes even against any research. They are students of the great debates, of the grand discussions, of the great themes. Amateur sociologists because they know how to cite the names in fashion; even though, with the huge schedule of psychology disciplines they follow, they do not manage to study them in more depth. They are probably already like their most influential teachers, choosing psychology, they will become psychologists, but do not accept this terrible label. They attend the same scientific congresses as their advisors, where they hear the same things as said in their research meetings at home, in a movement of self-legitimation. As Sá (2013) relates, social psychology can not be done solely with psychology; but it also can not be done without it.

Everything that has been mentioned also has an impact on the theorizing produced by constructionism in social psychology. In this respect we can inquire about which theory or figure from our field has emerged with an impact on the analysis of social phenomena. If we adopt one of the concepts "under erasure" in the postmodern perspective that inspires constructionism, that of "identity", a fundamental concept in social psychology, we observe that the timely criticism employed by constructionism against more essentialist notions of identity did not produce significant theoretical alternatives to the topic. As one of the inspirers of the approach declares: "The very concept with which we are dealing, 'identity', is overly complex, too poorly developed, and too little understood in contemporary social science to be definitively put to the test" (Hall, 2006, p. 8).

A number of ethnographic accounts tell us that cultural isolation is mainly responsible for the backwardness, barbarity, and ignorance in societies in general. In social psychology it is no different. We think that the tensioning between different ways of thinking is what is most beneficial for the production of knowledge in a world without absolute or neutral frames of reference. However, to produce contact it is necessary that the differences be engaged, included in dialogue, and acknowledged. This would permit a theoretical and methodological pluralism in social psychology that would bring many benefits to this area of knowledge, in general, and to the perspectives that constitute it, in the specific. It is this point, the possibilities of dialogue, that we will discuss next.

\section{Proposal for a New Field: Articulation and Tensioning}

Gergen (2002), a leading reference on constructionism in psychology, asserts that there are no rational grounds for an endless struggle between empiricism and constructionism. The encounter of these perspectives is essential to the development of our area. Redding (2001) proposes that the lack sociopolitical diversity in psychology has brought negative consequences for research, clinical practice, professional training, and social intervention. According to this author, the marginalization of opposing political 
positions, in various fields, does huge damage to our knowledge.

In the case of studies on prejudice, for example, the hegemony of political leftist thought among researchers has often led psychosocial research to confuse attitudes contrary to Affirmative Action Policies with racism (e.g., Kinder \& Sears, 1981; McConahay, 1986). At the opposite extreme, excessive conservatism of the right, dominant in other areas of the field may, for example, lead us to theorize about child development based on a traditional family model with a father, a mother, and children, ignoring other possibilities.

Not only the contrast of various political positions, but also of different styles and epistemological beliefs could benefit our area. As Geertz (2001, p. 176) states, in his reading of Bruner:

The path of our understanding of the mind does not reduce to a determined march toward an omega point where everything finally harmoniously fits; it is based on the repeated exposure of separate investigations, in such a way so that, again and again, in a seemingly endless manner, they require profound reconsiderations of one another. . . .
What seems necessary is the development of strategies that allow different constructs of mental reality, in the words of Bruner, to confront, decompose, energize, and de-provincialize each other, leading the venture erratically forward.

The aim, then, is not to reconcile approaches, integrating them as levels, assuming that some explain the basics and others the complex. The proposal is to place them in confrontation, stressing them through one another (Geertz, 2001). What is sought is not the eclectic and peaceful social psychologist; but the one uneasy, unsure of his/her assumptions, open and even prone to new possibilities of understanding.

Michael Burawoy (2009), in his discussion of the levels of analysis in sociology and their relation to practice, helps us to form a proposal for a dialogue between the psychologies more empiricist and those more constructionist. This author, by considering one type of knowledge production instrumental and another reflexive, and considering the type of clientele to whom the knowledge is directed, proposes the existence of a scenario of sociologies that complement each other, as we can see in Table 1.

Table 1

The Division of Sociological Labor

Type of knowledge

Type of audience
Academic
Extra-Academic

Instrumental Knowledge

Professional Sociology

Policy Sociology

Reflexive Knowledge

Critical Sociology

Public Sociology

Note. Extracted from Burawoy, 2009, p. 236.

According to Burawoy (2009), public sociology arises from direct contact, without mediation, between the sociologist and the public, from which arise theorizations about the connection between the individual micro-experience and the social macrostructure. Professional sociology is oriented to research programs that fit in a pre-defined theoretical framework, in which the thesis can not be questioned by the research- er. To question these assumptions, the researcher needs another body of specialized sociologists, those from critical sociology. Finally, policy sociology is geared to solve the problems of its clients (e.g., the State, NGOs, politicians, trade unions, social movements, etc.). Thus, concludes Burawoy (2009, p. 236): "As critical sociology involves a dialogue among sociologists about the foundations of professional sociology, 
public sociology involves a dialogue with publics beyond academia, and regarding the foundations of society". Sociological analysis cannot ignore the clash among these four fields, because only in this clash can sociology flourish. It is in this sense that the author defends the thesis of "antagonistic interdependence" between the sociologies:

Professional sociology draws its energy from the infusions from public sociology, advances under the pressures of critical sociology, and is often sustained by policy sociology. Likewise, public sociology could not exist, unless professional sociology did not conform, and sustained its autonomy vis-à-vis the publics with which it engages. It also depends on critical sociology to instill values that may help maintain or correct its course. In turn, critical sociology depends on its antagonist, professional sociology, without which it would have nothing to criticize! All these antagonisms are linked in a common division of labor. To the extent that professional sociology becomes irrelevant, critical sociology becomes dogmatic, policy sociology becomes servile, and public sociology becomes populism. (Burawoy, 2009, p. 240)

We think that the proposal presented for sociology fits perfectly in the field of social psychology. In a way such that our "professional social psychology" empiricist does not become irrelevant, and the "critical social psychology" constructionist does not regress into dogmatism, we need to expand the opportunities for contrast and understanding between these perspectives, creating spaces where the different psychologies can effectively dialogue, as has been proposed in several perspectives of linkage (Camino, 1996, 2005; Doise, 1982, 2002). Indeed, we can establish an arena of interfaces in which the more intra-individual level analyses, prevailing in more empiricist social psychology, may be complemented or contrasted with situational or interpersonal level analyses, focused on the influences of the immediate interactional situation; these, in turn, will benefit from the emphasis on the positional level, which highlights the social status of the groups and the power relations established, and on the ideological level, considering also the role of the norms, social representations, and belief systems of each society in psychological processes. All of that would enrich both the production of a more instrumental knowledge from a more empiricist psychology, as well as the criticism and adjustments of course proposed by constructionist psychology.

We therefore need to replace our current "antagonistic independence" with "antagonistic interdependence". All this can make social psychology have a more decisive role in its contact with the public and in the development and implementation of public policies.

\section{References}

Alvaro, J. L., \& Garrido, A. (2006). Psicologia Social: Perspectivas psicológicas e sociológicas. São Paulo, SP: McGraw Hill.

Bauer, M., \& Gaskell, G. (2002). Pesquisa qualitativa com texto imagem e som. Petrópolis, RJ: Vozes.

Billig, M. (2008). Argumentando e pensando: Uma abordagem retórica à psicologia social. Petrópolis, RJ: Vozes.

Blumer, H. (1958). Race prejudice as a sense of group position. The Pacific Sociological Review, 1(1), 3-7.

Bruner, J. (1990). Actos de significado: mas allá de la revolución cognitiva. Madrid, España: Alianza Editorial.

Burawoy, M. (2009). A sociologia pública em tempos de Barack Obama. Caderno CRH, 22(56), 233-244.

Camargo, K. R., Jr. (2012). O lugar da crítica, da memória e da afetividade. In A. M. Jacó-Vilela \& L. Sato (Orgs.), Diálogos em Psicologia Social (pp. 1-24). Rio de Janeiro, RJ: Scielo Books.

Camino, L. (1996). Uma Abordagem Psicossociológica no Estudo do Comportamento Político. Psicologia e Sociedade, 8, 16-42.

Camino, L. (2005). A construção de uma perspectiva psicossociológica no estudo do comportamento politico. In A. R. R. Torres, M. E. O Lima, \& J. B. da Costa (Orgs.), O estudo das atividades políticas: A Psicologia Política na perspectiva 
psicossociológica. Goiânia, GO: Pontifícia Universidade Católica de Goiás.

Camino, L., \& Torres, A. R. R. (2011). Origens e desenvolvimento da Psicologia Social. In A. R. R. Torres, L. Camino, M. E. O. Lima, \& M. E Pereira (Orgs.), Psicologia Social: Temas e teorias (pp. 451-500). Brasília, DF: Technopolitik.

Castañon, G. A. (2004). Construcionismo social: Uma crítica epistemológica. Temas em Psicologia, 12(1), 67-81.

Dimenstein, M. (2000). A cultura profissional do psicólogo e o ideário individualista: Implicações para a prática no campo da assistência pública à saúde. Estudos de Psicologia (Natal), 5(1), 95-121.

Doise, W. (1982). L'explication en psychologie sociale. Paris: Presses Universitaires de France.

Doise, W. (2002). Da Psicologia Social à Psicologia Societal. Psicologia: Teoria e Pesquisa, 18(1), 27-35.

Dovidio, J. F., \& Gaertner, S. L. (2000). Aversive racism in selection decisions: 1989 and 1999. Psychological Science, 11, 319-323.

Farr, R. (1999). Representações sociais: A teoria e sua história. In P. Guareschi \& S. Jovchelovitch (Orgs), Textos em representações sociais (pp. 31-59). Petrópolis, RJ: Vozes.

Gaertner, S. L., \& Dovidio, J. F. (1986). The aversive form of racism. In J. F. Dovidio, \& S. L. Gaertner (Eds.), Prejudice, discrimination, and racism: Theory and research (pp. 61-89). Orlando, FL: Academic Press.

Geertz, C. (2001). Nova luz sobre a Antropologia. Rio de Janeiro, RJ: Jorge Zahar.

Gergen, K. J. (1973). Social psychology as history. Journal of Personality and Social Psychology, 26, 309-320.

Gergen, K. J. (1978). Toward Generative Theory. Journal of Personality and Social Psychology, 36, 1344-1360.

Gergen, K. J. (1994). Exploring the postmodern: Perils or potentials? American Psychologist, 49, 412-416.

Gergen, K. J. (2002). Beyond the Empiricist/Constructionist Divide in Social Psychology. Personality and Social Psychology Review, 6, 188-191.
Glick, P., \& Fiske, S. T. (2001). An ambivalent alliance: Hostile and benevolent sexism as complementary justifications for gender inequality. American Psychologist, 56, 109-118.

Hall, S. (2006). A identidade cultural na pós-modernidade (11. ed.). Rio de Janeiro, RJ: DP\&A Editora.

Henrich, J., Heine, S. J., \& Norenzayan, A. (2010). The weirdest people in the world? Behavioral and Brain Sciences, 33, 1-75

Hepburn, A. (2003). An introduction to critical social psychology. London: Sage.

Jackman, M. R. (1994). The Velvet Glove. Berkeley, CA: University of California Press.

Jacques, M. das G. (1998). Identidade. In M. das G. Jacques, M. N. Strey, N. M. G. Bernardes, P. A. Guareschi, S. A. Carlos, \& T. M. Fonseca (Eds.), Psicologia Social Contemporânea: Livro-texto (pp. 159-167). Petrópolis, RJ: Vozes.

Jones, D. (2010). A WEIRD view of human nature skews psychologists' studies. Science, 328, 1627.

Jost, J. T., \& Hardin, C. D. (1996). The practical turn in psychology: Marx and Wittgenstein as social materialists. Theory \& Psychology, 6, 385-393.

Jost, J. T., \& Kruglanski, A. W. (2002). The Estrangement of Social Constructionism and Experimental Social Psychology: History of the Rift and Prospects for Reconciliation. Personality and Social Psychology Review, 6, 168-187.

Kinder, D. R., \& Sears, D. O. (1981). Prejudice and politics: Symbolic racism versus racial threats to the good life. Journal of Personality and Social Psychology, 40, 414-431.

Kruglanski, A. W. (2001). That "Vision Thing": The State of Theory in Social and Personality Psychology at the Edge of the New Millennium. Journal of Personality and Social Psychology, 80(6), 871-875.

Leite, J., \& Dimenstein, M. (2002). Mal-estar na Psicologia: A insurreição da subjetividade. Revista Mal-Estar e Subjetividade, 2(2), 9-26.

Lévi-Strauss, C. (2000) Raça e história. Lisboa, Portugal: Presença. (Original publicado em 1952)

Lima, M. E. O. (2011). Preconceito. In A. R. R. Torres, L. Camino, M. E. O. Lima, \& M. E Pereira (Orgs.), Psicologia Social: Temas e teorias (pp. 451-500). Brasília, DF: Technopolitik. 
Lima, M. E. O., \& Techio, E. M. (2013). Academic training in Social Psychology in Brazil and South America. Estudos de Psicologia (Natal), 18(1), 75-82.

Mancebo, D. (2002). Modernidade e produção de subjetividades: Breve percurso histórico. Psicologia: Ciência e Profissão, 22(1), 100-111.

Mayorga, C., Rasera, E., \& Prado, M. A. M. (2012). Editorial. Psicologia \& Sociedade, 24(3), 491493.

McConahay, J. B. (1986). Modern racism, ambivalence, and the modern racism scale. In J. F. Dovidio \& S. L. Gaertner (Eds.), Prejudice, Discrimination, and Racism (pp. 91-125). New York: Academic Press.

McGuire, W. J. (1973). The yin and yang of progress in Social Psychology: Seven koan. Journal of Personality and Social Psychology, 26(3), 446456.

Méllo, R. P., Silva, A. A., Lima, M. L. C., \& Di Paolo, A. F. (2007). Construcionismo, práticas discursivas e possibilidades de pesquisa em Psicologia Social. Psicologia \& Sociedade; 19(3), 26-32.

Moscovici, S. (1990). A máquina de fazer deuses. Rio de Janeiro, RJ: Imago.

Pereira, C. (2007). Preconceito, normas sociais $e$ justificações da discriminação: $O$ modelo da discriminação justificada (Tese de doutorado, Instituto Universitário de Lisboa, Lisboa, Portugal).

Pereira, C., Torres, A. R. R., \& Almeida, S. T. (2003). O preconceito na perspectiva das representações sociais: Análise da influência de um discurso justificador da discriminação no preconceito racial. Psicologia: Reflexão e Crítica, 16(1), 95107.

Pereira, C., \& Vala, J. (2011). From prejudice to discrimination in egalitarian and meritocratic contexts. Manuscript submitted for publication.

Potter, J., \& Wetherell, M. (1987). Discourse and Social Psychology: Beyond Attitudes and Behaviour. London: Sage.

Pratto, F., Sidanius, J., Stallworth, L. M., \& Malle, B. F. (1994). Social dominance orientation: A personality variable predicting social and political attitudes. Journal of Personality and Social Psychology, 67, 741-763.
Quillian, L. (2006). New approaches to understanding racial prejudice and discrimination. Annual Review of Sociology, 32, 299-328.

Redding, R. E. (2001). Sociopolitical diversity in Psychology: The Case for Pluralism. American Psychologist, 56(3), 205-215.

Rey, F. G. (2004). O social na Psicologia e a Psicologia Social: A emergência do sujeito. Petrópolis, RJ: Vozes.

Sá, C. P. de (2013). On the routes of Social Psychology in Brazil. Estudos de Psicologia, 18(1), 93-98.

Sidanius, J. (1993). The psychology of group conflict and the dynamics of oppression: A social dominance perspective. In S. Iyengar \& W. McGuire (Eds.), Explorations in Political Psychology (pp. 183-219). Durham, NC: Duke University Press.

Silva, R. N. da (2004, maio/ago.). Notas para uma genealogia da Psicologia Social. Psicologia \& Sociedade, 16(2), 12-19.

Souza, L. C. G., \& Souza, E. A., Filho. (2009). O lugar da Psicologia Social na formação dos psicólogos. Psicologia \& Sociedade, 21(3), 383390.

Tajfel, H. (1983). Grupos humanos e categorias sociais. Lisboa, Portugal: Livros Horizonte.

Tittoni, J., \& Jacques, M. G. C. (1998). Pesquisa. In M. das G. Jacques, M. N. Strey, N. M. G. Bernardes, P. A. Guareschi, S. A. Carlos, \& T. M. Fonseca (Eds.), Psicologia Social Contemporânea: Livro-texto (pp. 73-85). Petrópolis, RJ: Vozes.

Vygotsky, L. S. (1996). Pensamento e linguagem. São Paulo, SP: Martins Fontes.

Weinberg, D. (2008). The philosophical foundations of constructionist research. In J. A. Holstein \& J. F. Gubrium (Eds.), Handbook of Constructionist Research (pp. 13-40). New York: Guilford Press.

Woodiwiss, A. (1990). Social theory after postmodernism: Rethinking production, law and class. London: Pluto Press. 